\title{
Dichotomy of EFL reading: Metacognition vs. proficiency
}

\author{
Nesrin Ozturk ${ }^{\mathrm{a} *}$, Ferah Senaydin ${ }^{\mathrm{b}}$ \\ ${ }^{a}$ Ege University, School of Foreign Languages, Izmir-35100, Turkey \\ ${ }^{b}$ Ege University, School of Foreign Languages, Izmir-35100, Turkey
}

\section{APA Citation:}

Ozturk, N., \& Senaydin, F. (2019). Dichotomy of EFL reading: Metacognition vs. proficiency. Journal of Language and Linguistic Studies, 15(2), 605-617.

Submission Date: 12/1/2019

Acceptance Date: 7/2/2019

\begin{abstract}
This study examined a) the effects of metacognition and proficiency on EFL reading performance and b) the relation of metacognition and EFL reading performance. Data were collected by Metacognitive Awareness Inventory (MAI) and reading scores were examined. By variance analyses, we found that reading scores and metacognitive knowledge show variations across proficiency levels. There were no effects of time, timeXclass, and timeXproficiency on metacognition. When tests incorporated higher order thinking skills, participants' metacognitive knowledge or regulation correlated with reading scores, positively. Although trends that can explain differences in metacognition did not follow a pattern; it was observed that different proficiency groups benefited from training differently; for low- and mid-proficiency groups, a slight increase in metacognition regulation; and for high-proficiency group, a refinement in metacognitive knowledge was observed. We suggest instructional and assessment practices incorporate metacognition regarding learners' proficiency levels. Therefore, all students might see the relevance of metacognition and take responsibility for it.
\end{abstract}

Keywords: metacognition, EFL, reading, regulation, proficiency

\section{Introduction}

Flavell (1979) proposed that thinking about thinking pertains to metacognition. That is, cognitions can be monitored and controlled through actions and interactions of metacognitive knowledge, strategies, and experiences (Flavell, 1979). Research reported that metacognition positively impacts reading awareness, skills, comprehension, vocabulary, and performance (Boulware-Gooden, Carreker, Thornhill, \& Joshi, 2007; Curwen, Miller, White-Smith, \& Calfee, 2010; Veenman, Van Hout-Wolters, \& Afflerbach, 2006). Research also demonstrated that metacognition can successfully be taught (Ozturk, 2015; Pintrich, 2002; Schraw, 1998; Tanner, 2012; Zohar \& Ben David, 2009). That is, when learners are trained for metacognition, their knowledge of self as a reader, different text-structures, genres and tasks, and strategies increase. Also, they learn how to plan reading by orienting themselves to goals and task demands, monitor comprehension, regulate strategies to fix any failures, and evaluate cognitive endeavours (Ozturk, 2017b).

Regarding the effects of globalization (Iwai, 2011), reading's being a viable means for language ability (Tavakoli, 2014; Taylor, Stevens, \& Asher, 2006), and its impacts on academic success across educational contexts (Taylor et al., 2006); many students should develop a literacy competence in

\footnotetext{
${ }^{*}$ Corresponding author. Tel: $+(0232) 3886759$

E-mail address: ozturknesrin@gmail.com
} 
English as a second (ESL) or foreign (EFL) language (L2, from now on). Available research on metacognition and L2 reading suggests similar findings as first-language reading research does. Many studies reported that there might be a positive relation between L2 readers' metacognition and reading processes (Chern, 1993; Zhang \& Seepho, 2013); comprehension skills (Ahmadi, Ismail, \& Abdullah, 2013; Salataci \& Akyel, 2002); performance (Karami \& Hashemian, 2012; Phakiti, 2003; Zhang \& Seepho, 2013); and language proficiency (Zhang, 2001). Some researcher including Muñiz-Swicegood (1994) and Takallou (2011) found that ESL or EFL learners' reading scores improved following metacognition trainings. In line with these findings, Alsheikh and Mokhtari (2011), Barnett (1988), and Mokhtari and Reichard (2004) stated that proficient L2 readers may possess more awareness and use metacognitive strategies effectively for and during L2 reading experiences.

\subsection{Research questions}

Previous findings confirmed that metacognition can be an important factor for L2 reading, metacognitive trainings can promote metacognitive knowledge and regulation, and proficient readers might have more metacognition and responsibility for learning. Therefore, based on these arguments and the potential relations of metacognition, L2 performance, and proficiency; in this study, the following will be studied;

1. Does L2 students' metacognition and reading performance change following a metacognition training?

2. Does L2 students' metacognition and reading performance change by proficiency?

3. Is there a relation between students' metacognition and L2 reading performance?

4. Can the nature of reading tests influence L2 readers' employment of metacognition?

Before we explain the methodology employed in this study, it is also important to reveal that one of the gaps in the literature pertained to a sufficiently explained pedagogy of metacognition. Most research examining effects of metacognition trainings did not explain how they implemented instructional practices (Ozturk, 2015, 2017b). Therefore, to help transfer and enable sustainability of metacognition instruction into mainstream classrooms, the first author developed a research-based pedagogy of metacognition (see PMR in Ozturk, 2017). In the following section, we will provide key components of this pedagogy and mention instructional practices.

\subsection{Metacognition Training}

Based on social principles of learning that include social cognitive theory (Bandura, 1986; 1971), self-regulated learning (Zimmerman, 2000, 2002), social constructivism (Vygotsky, 1978), and following an in-depth-review of metacognition literature, Ozturk (2017) developed a generic training program to help develop students' metacognition in reading classrooms. This training program follows a gradual release of responsibility model and it consists of seven crucial components including; (1) fostering learners' metacognitive knowledge, (2) scaffolding students' strategic reading experiences, (3) encouraging student's independence with strategic reading, (4) assessing metacognition, (5) adopting goal directedness, (6) integrating language of thinking, and (7) prolonging metacognition training.

In this study, metacognition instruction implemented by the following practices; first teachers' and then students' goal-setting for each reading experience; using language of thinking; teachers' explaining reciprocity between cognition and metacognition; teaching strategies explicitly; holding metacognitive discussions; teachers' modelling strategic reading, using action plans or analogies; students' practicing strategic reading first with the teacher and then in (small) groups; students' reasoning about and thinking-aloud strategic reading; students' questioning others' thinking; teachers' providing students 
scaffolding and constructive feedback; teachers' creating more opportunities for students' independence with metacognition; teachers' assessing students' strategic reading; students' doing self-assessment; and prolonged training.

In the following section, we will portray how we merged those components into this study (see Table 2). We basically implemented 4 main components (fostering learners' metacognitive knowledge; scaffolding students' strategic reading experiences; encouraging student's independence with strategic reading; and assessing metacognition) in classrooms and scaffolded them using the other facets (adopting goal directedness; integrating language of thinking; and prolonging metacognition training).

\section{Method}

\subsection{Sample / Participants}

This study was conducted at a state university, School of Foreign Languages, in Turkey. A total of 63 participants, between 17-25 years old, involved in this study. The participants studied English as a foreign language in 4 different classes of mixed proficiency levels. According to Common European Framework of Reference for Languages, during data collection period participants were A1 students; basic users of English.

\subsection{Instrument $(s)$}

This study was conducted by the principles of quantitative research methodology; we examined students' institutional reading scores in relation to Metacognition Awareness Inventory (MAI) scores. After we collected reading scores of the first three exams (R1, R2, and R3) from the school's academic database, we collected metacognition data via MAI. Metacognitive Awareness Inventory is a 52-item scale developed by Schraw and Dennison (1994). It is a two-factor instrument incorporating metacognitive knowledge and metacognitive regulation. We will discuss the characteristics of reading tests in the following separate section in detail since they created metacognitive reading experiences for participants, if at all.

\subsubsection{Characteristics of reading tests}

For the best interpretation of our findings, it is important to disseminate the characteristics of reading tests regarding potential metacognitive experiences. The School of Foreign Languages gave 3 reading tests in the semester. The first test was given on the $6^{\text {th }}$ week of the semester. Following this, 2 other tests were given at every $4^{\text {th }}$ week. All tests were graded out of 25 .

The first reading test (R1) was composed of three texts and 25 questions. The first text pertained to graffiti and skimming for the topic and main idea, scanning (2), and summarizing skills were tested. The second text read the story of a Japanese anime; Spirited Away. The test included questions of skimming for the main idea and scanning (7) skills. Water ballet dancing was the theme of the final text and it pertained to the daily schedule of a school girl doing water ballet dancing. 6 of the questions tested scanning skill and one question assessed students' skimming for the topic skill. Examining the overall distribution of the questions, we realized that scanning skill was tested excessively. That is, $60 \%$ of the questions tested scanning. Skimming was also tested at each subsection by having students find the main idea or topic (16\%). Lastly, summarizing (24\%) was tested by providing students necessary vocabulary items and a paragraph with blanks. In this exam, there were no questions to practice higher order thinking (HOT) skills. 
The second reading test (R2) was similarly composed of 3 texts and 25 questions. The first text pertained to unusual festivals from different parts of the world. This text was accompanied with 5 scanning questions, 2 reference questions that needed the use of contextual clues, and 3 inference questions. The second text read some historical and cultural characteristics of Buenos Aires and this text was accompanied with questions testing skimming for the topic (2) and scanning (2) skills. Students, moreover, read a text about the power of positive thinking and they were tested for contextual clues (3), scanning (4), and summarizing (4) by utilizing the vocabulary items to fill in the blanks. In contrast to the first test, the second test had different questions assessing students' use of contextual clues and inference skills. However, general characteristics of the test did not change considerably; in the second exam scanning (44\%), skimming (8\%), and summarizing (16\%) skills dominantly tested. Only $32 \%$ of the questions required students to use HOT.

The final reading test (R3) also included 3 texts and 25 questions. The first text told about Hebrides Islands' geographical and touristic characteristics. The first 8 questions tested scanning skill, one question tested students' skimming skill for the topic, and there was only two question requiring students to use contextual clues to find out a pronoun. The second text pertained to The Life of Pi. First five question tested summarizing by reordering the provided sentences. The next 3 questions tested students' using reference clues for pronouns or vocabulary items. The final question for this text tested scanning skill. Finally, the last text read how Math's teacher taught math to his low-income students. One of the questions tested skimming skill for the main idea and the rest 4 tested scanning for the details. Similar to previous exams, the last exam was overwhelmed with lower level thinking skills (70\%); skimming (8\%), scanning (52\%), and summarizing (20\%) skills were tested. However, only $20 \%$ of the questions tapped on higher order thinking skills via reference or contextual clue questions.

The analysis of question types revealed that only $32 \%$ of the second and $20 \%$ of the third exam required students to use HOT skills, as can be seen in Table 1Hata! Başvuru kaynağı bulunamadı.. That is, all exams mostly tested lower order thinking (LOT) skills. The interrater reliability was checked by the researchers. For this purpose, we categorized all exam questions into lower- or higher-order thinking skills and then calculated the frequencies. Following the analysis, the interrater reliability was found $98 \%$.

Table 1. Distribution of questions on each exam regarding thinking skills

\begin{tabular}{rcc}
\hline Exam & LOT skills & HOT skills \\
\hline 1st Reading exam & 25 & - \\
2nd Reading exam & 17 & $8(32 \%)$ \\
3rd Reading exam & 20 & 5 \\
\hline
\end{tabular}

\subsection{Data Collection Procedure}

This study continued for 15 weeks and it progressed through 3 stages; preparatory, treatment, and post-treatment. During the first stage, while we followed school's reading curriculum, we informally assessed participants' metacognitive knowledge and regulation to understand the relevance of the treatment. We realized that there were variations in participants' metacognition; therefore, as some previous findings argued we took proficiency into account and later considered analyzing findings considering this variable, as well.

We initially had participants complete MAI before they took R1. Then, based on both reading scores and MAI scores, we implemented metacognition training program for 8 weeks. Participants were exposed to different instructional practices of metacognition program each week. At the end of the 4th 
week, participants were given R2. Following these, participants took R3 and completed MAI, again as can be seen Table 2.

Table 2. Data collection tools and procedures

\begin{tabular}{|c|c|c|}
\hline Weeks & Procedures & Tools \\
\hline First 6 weeks & Implementation of schools' reading curriculum & \\
\hline 7 & $\begin{array}{l}\text { 1st Reading test } \\
\text { Analysis of question types }\end{array}$ & MAI, R1 scores \\
\hline $8-12$ & $\begin{array}{l}\text { Integration of metacognition training for } 2 \text { hours each week } \\
\text { (fostering learners' metacognitive knowledge; scaffolding } \\
\text { students'strategic reading experiences } \\
\text { * supported by goal directedness and language of thinking) }\end{array}$ & \\
\hline 9 & $\begin{array}{l}\text { 2nd Reading test } \\
\text { Analysis of question types }\end{array}$ & R2 scores \\
\hline $10-14$ & $\begin{array}{l}\text { Cont'd metacognition training for } 2 \text { hours each week } \\
\text { (encouraging student's independence with strategic reading; } \\
\text { assessing metacognition } \\
\text { *supported by goal directedness, language of thinking, and } \\
\text { prolonged training) }\end{array}$ & \\
\hline 15 & $\begin{array}{l}\text { 3rd Reading test } \\
\text { Analysis of question types }\end{array}$ & MAI, R3 \\
\hline
\end{tabular}

While implementing metacognition training in 3 different experimental classes, we aimed to maximize the homogeneity of our teaching practices. For this purpose, we discussed the aim of the modules each week and negotiated instructional practices before we implemented them in each class. We also used the same materials, if need be.

\section{Results}

In the following section, we provided findings grouped by students' metacognition and proficiency as the literature highlighted. Following the assumption-checks for each statistical analysis, we run some parametric and non-parametric tests to answer each research question.

\subsection{Does L2 students' metacognition and reading performance change following metacognition training?}

\section{i.l. Mean difference analyses by metacognition}

Normality assumption for metacognition (metacognitive knowledge and metacognitive regulation) was confirmed at both pre- and post-treatment levels. Homogeneity of variances was also ensured by Levene's statistics. Therefore, the examination of any differences by metacognition treatment and proficiency levels was done by running parametric tests (ANOVA and Repeated Measures ANOVA).

Firstly, whether being exposed to metacognition treatment in different classes created any differences in metacognition (metacognitive knowledge; MK and metacognitive regulation; MR) was examined. It was found that MK and MR at any stages (pre- and post- treatment) was statistically different across 
different classes at p. 05, F(3, 59) $=6.18,3.69,3,3.53 \mathrm{p}<.05$, respectively for MKpre, MRpre, MKpost, and MRpost. However, the differences in mean scores of MK or MR did not portray a meaningful trend to attribute it to any factors beyond what we examined.

Analysing the post-hoc results (LSD and Bonferroni) as can be seen on Table 3, we found that one of the experimental classes (36) had a significantly different mean of MKpre from the other two experimental (4 and 6) and control (37) classes. For MKpost, only one experimental class (36) was significantly different from the rest. Moreover, for the MRpre, the control (37) and one experimental classes (36) were significantly different from each other and one experimental class (6) was statistically different than the control class (37). For MRpost, only one of the experimental classes (36) was significantly different from the rest. Regarding the inconsistency in metacognition's change across classes and an increase in control groups' metacognition, it may not be valid to hypothesize a reasonable factor to explain the mean differences in MK and MR scores at each stage without going beyond our variables or data.

Table 3. Descriptive statistics for MK and MR by classes and stages

\begin{tabular}{|c|c|c|c|c|c|}
\hline & & MKpre & MRpre & MKpost & MRpost \\
\hline \multirow[t]{6}{*}{ Classes } & & $\mathrm{M} \quad \mathrm{SD}$ & $\mathrm{M} \quad \mathrm{SD}$ & $\mathrm{M} \quad \mathrm{SD}$ & $\mathrm{MSD}$ \\
\hline & DN4* & $3.66(.47)$ & $3.48(.45)$ & $3.81(.53)$ & $3.32(.52)$ \\
\hline & DN6* & $3.76(.58)$ & $3.68(.54)$ & $3.68(.65)$ & $3.69(.65)$ \\
\hline & DN36* & $4.31(.37)$ & $3.87(.45)$ & $4.21(.56)$ & $3.94(.65)$ \\
\hline & DN37 & $3.86(.21)$ & $3.31(.29)$ & $3.74(.23)$ & $3.52(.21)$ \\
\hline & Total & $3.88(.51)$ & $3.60(.49)$ & $3.86(.57)$ & $3.62(.60)$ \\
\hline
\end{tabular}

By these findings, we run two repeated measures ANOVA for MK and MR to find out the effects of time and timeXclass on MK and MR. Repeated measures ANOVA tests with Greenhouse-Geisser correction revealed that there was no significant effect of time and timeXclass on MK $F(1,59)=.359$, $(\mathrm{p}=.556)$ and $\mathrm{F}(3,59)=1.38,(\mathrm{p}=.25)$, respectively and on MR $\mathrm{F}(1,59)=.421,(\mathrm{p}=.519)$ and $\mathrm{F}(3$, $59)=1.92,(\mathrm{p}=.13)$, respectively. We expected that a prolonged metacognitive training would serve some improvement. However, as seen in the following graphs, the training in this study helped refinement; metacognitive knowledge and regulation started to follow similar trends.
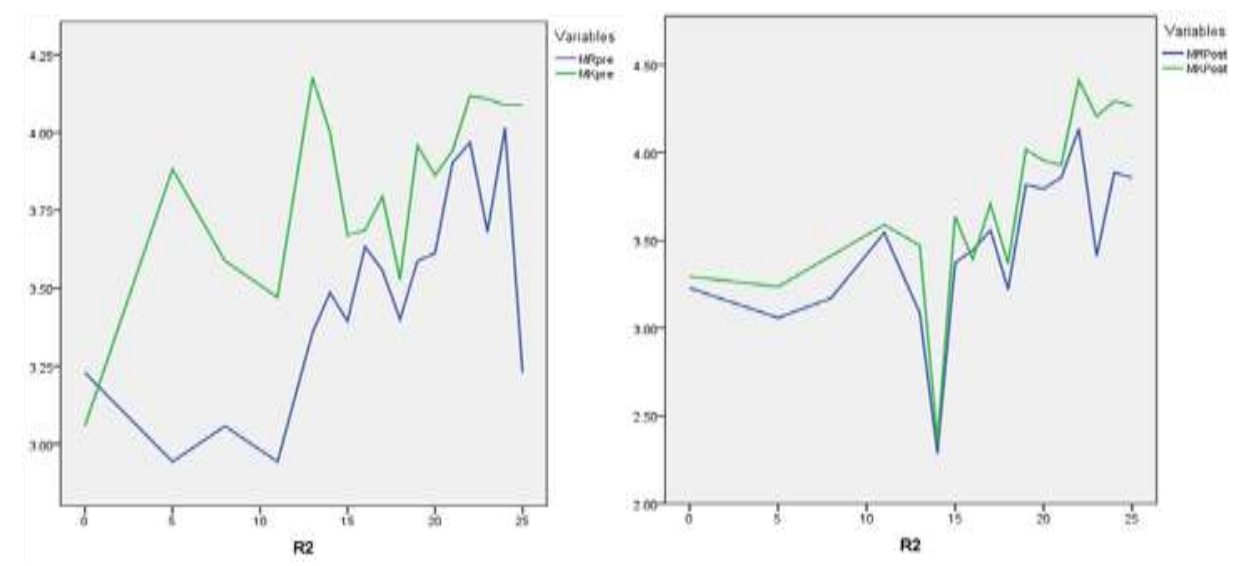

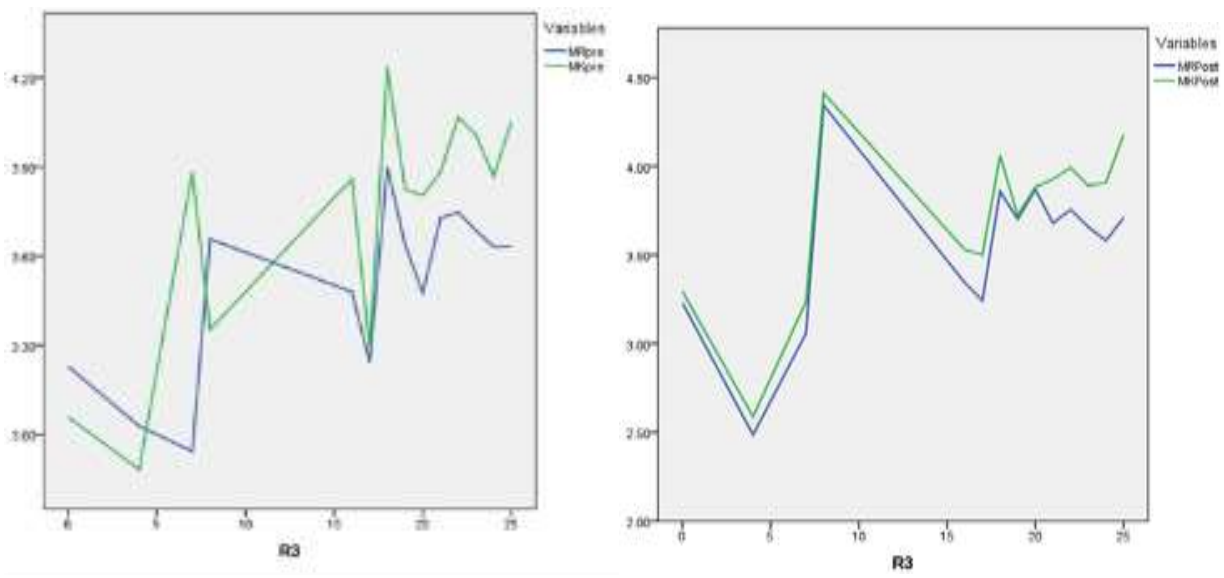

Figure 1. Graphs of metacognition and reading performance

Following these tests of metacognition, we analysed reading performance scores as there might be some variances among classes, maybe independent of metacognition.

\section{i.I. .. Mean difference analyses of reading performance by classes}

A set of rank-comparison tests was run to find out whether there was a significant difference in reading scores among different classes. Because reading scores were distributed non-normally and the $\mathrm{n}$ for each subgroup was small and unequal to endure violation of normality assumption, initially a Kruskal-Wallis test was run. The results showed that there was not a statistically significant difference in any reading test scores across different classes, $\chi 2(3)=3.69,5.40,1.02 \mathrm{p}>.05$, with a mean rank test score of 20.52 for $\mathrm{R} 1 ; \chi 2(3)=5.40, \mathrm{p}>.05$, with a mean rank test score of 18.63 for $\mathrm{R} 2$; and $\chi 2(3)=$ $1.02, \mathrm{p}>.05$, with a mean rank test score of 20.65 for R3.

\subsection{Does L2 students' metacognition and reading performance change by proficiency?}

Following these findings, a new analysis was run based on proficiency as the literature highlighted its importance. For this purpose, we initially examined R1 scores by the percentiles $(33 \%, 63 \%$, and $100 \%$ ) and then formed proficiency groups. By so, low proficiency group was composed of 21 students with a reading score between 10 and 19, mid-proficiency group involved 20 students who scored 20 to 22, and the rest 22 students formed high-proficiency group and scored 23 to 25 on R1 exam out of 25.

\section{i.2. /. Mean difference analyses of metacognition by proficiency}

One-way ANOVA test was run by proficiency and it was found that only MKpost scores varied across proficiency levels $\mathrm{F}(2,60)=4.35, \mathrm{p}=.01$. Analysing post-hoc results, we found that average for low-proficiency group was 3.6, for mid- proficiency was 3.7, and for high-proficiency group was 4.13; these scores were statistically different from each other.

Table 4. Descriptive statistics for MK and MR by proficiency

\begin{tabular}{|c|c|c|c|c|}
\hline & MKpre & MRpre & MKpost & MRpost \\
\hline Proficiency levels & $\begin{array}{ll}\mathrm{M} & \mathrm{SD} \\
\end{array}$ & $\begin{array}{ll}\mathrm{M} & \mathrm{SD} \\
\end{array}$ & $\begin{array}{ll}\mathrm{M} & \mathrm{SD} \\
\end{array}$ & $\mathrm{M}$ SD \\
\hline Low & $3.80(.48)$ & $3.47(.46)$ & $3.66(.56)$ & $3.54(.55)$ \\
\hline Mid & $3.82(.52)$ & $3.58(.59)$ & $3.76(.58)$ & $3.61(.73)$ \\
\hline High & $4.01(.53)$ & $3.75(.39)$ & $4.13(.47)$ & $3.70(.51)$ \\
\hline Total & $3.88(.51)$ & $3.60(.49)$ & $3.86(.57)$ & $3.62(.60)$ \\
\hline
\end{tabular}


Following these procedures, we also run two repeated measures ANOVA for MK and MR to find out the effects of time and timeXproficiency on MK and MR. Repeated measures ANOVA tests with Greenhouse-Geisser correction revealed that there was no significant effect of time and timeX proficiency on MK $\mathrm{F}(1,60)=.20,(\mathrm{p}=.651) ; \mathrm{F}(2,60)=1.90$, $(\mathrm{p}=.15)$, respectively and on MR $\mathrm{F}(1$, $60)=.07,(\mathrm{p}=.79) ; \mathrm{F}(2,60)=.45,(\mathrm{p}=.63)$, respectively. However, analyzing the raw scores, we realized that MK scores dropped in low- and mid-proficiency groups in time while high-proficiency group gained more metacognitive knowledge. Whereas, low- and mid-proficiency groups gained some metacognitive regulation while high-proficiency group's MR score dropped.

\section{i.2. . Mean difference analyses of reading performance scores by proficiency}

Running another Kruskal-Wallis test examining the rank differences of reading scores by proficiency, we found statistically significant differences in all reading test scores among different proficiency levels, $\chi 2(2)=55.6,10,6.83 \mathrm{p}<.05$ for R1, R2, and R3 respectively. Post-hoc tests for R1 showed that all proficiency groups ( $L P . R=11, M P . R=31.5$, and HP.R=52.5) were significantly different from each other $\mathrm{p}<.05$. Whereas post-hoc for $\mathrm{R} 2$ showed that low-proficiency $(\mathrm{R}=23.7)$ and highproficiency $(\mathrm{R}=41.2)$ groups' reading score ranks were significantly different $\mathrm{p}<.05$. Mid-proficiency group scored relatively closer to low-proficiency group with $\mathrm{R}=30$. Finally, post hoc analysis for $\mathrm{R} 3$ showed that high- $(\mathrm{R}=37)$ and low- $(\mathrm{R}=23.5)$ proficiency groups' scores differed significantly. Midproficiency group's score got closer to high proficiency group with a rank score of 35.4 (see Table 5).

Table 5. Rank reading scores for different proficiency groups

\begin{tabular}{ccccc}
\hline & & Low-prof. & Mid-prof. & High-prof. \\
\hline Exams & R1 & 11 & 31.5 & 52.5 \\
& R2 & 23.7 & 30 & 41.2 \\
& R3 & 23.5 & 35.4 & 37 \\
\hline
\end{tabular}

\subsection{Is there a relation between metacognition and $L 2$ reading performance?}

Following previous analyses that heralded reading scores showed variations by proficient but not by metacognition, we run correlation tests to examine the relation between metacognition and reading scores for the best interpretation of our findings.

\section{i.r. I. Analyses of the relation between metacognition and reading performance}

To examine the relation between reading scores and metacognition, a Spearman's Rho test was run. The analysis showed that two variables (reading scores and metacognition) were correlated positively. Considering treatment started a month before R2, the correlation between metacognition and reading scores should be read carefully as highlighted. By the correlation analysis, we found that MK has a relation with reading scores at R2 and R3, and MR only correlated with R2 exam as can be seen in Table 6. 
Table 6. The relation between reading performance and metacognition

\begin{tabular}{clllllll}
\hline & R1 & R2 & R3 & MKpre & MRpre & MKPost & MRPost \\
\hline R1 & 1.000 & & & & & & \\
R2 & $.436^{* *}$ & 1.000 & & & & & \\
R3 & $.347^{* *}$ & $.512^{* *}$ & 1.000 & & & & \\
MKpre & .123 & $\mathbf{. 3 1 5}$ & .195 & 1.000 & & & \\
MRpre & .213 & $\mathbf{. 3 4 7}^{* *}$ & .140 & $\mathbf{. 7 4 2} * *$ & 1.000 & & \\
MKPost & $.336^{* *}$ & $\mathbf{. 6 4 3}^{* *}$ & $\mathbf{. 3 4 3}$ & & & \\
MRPost & .138 & $\mathbf{. 4 0 7}^{* *}$ & .166 & $\mathbf{. 6 1 1}^{* * *}$ & $\mathbf{. 6 6 8}^{* *}$ & 1.000 & \\
\hline
\end{tabular}

\subsection{Can the nature of reading exams influence L2 readers' employment of metacognition?}

In this study, institutional reading exams had different characteristics regarding thinking skills; therefore, taking such characterization into consideration can help interpret variations in reading scores and their relation with metacognition. R1 exam contained no higher order questions. In accordance with this fact, this study found no significant correlation between R1 scores and either MK or MR scores ( $\mathrm{p}$ $>$.05). On the other hand, R3 exam contained questions requiring higher-order thinking skills by only $20 \%$. As seen on Table 6, there was a correlation only between MKpost and R3 scores. Whereas the percentage of higher-order thinking skills in R2 was 32\%. Examining the correlation between reading performance and metacognition, a significant positive correlation was observed both on metacognitive knowledge and regulation aspects. That leads us to conclude that as $\mathrm{R} 2$ relies more on questions aiming for higher order thinking skills, it might create metacognitive experiences where students read strategically. Correlations found between a) R2 and MK and MR scores and b) R3 and MKpost can, therefore, suggest that test-question types might initiate practices of metacognition.

\section{Discussion and Conclusions}

This study's findings can be grouped into two categories; practical outcomes and theoretical insights. To start with practical findings that can indeed help with classroom instruction and research implications, we found that EFL reading scores might be correlated with metacognitive knowledge and metacognitive regulation specifically in the presence of metacognitive experiences. These findings aligned with previous research including; Karami and Hashemian (2012), Phakiti (2003), Tavakoli (2014), and Zhang and Seepho (2013) as regards the correlation between L2 reading performance and metacognition. However, we also found that significant mean differences in reading scores can be observed only across L2 proficiency levels. This can be because reading performance might be stimulated by sufficient second language proficiency as Tavakoli (2014) argued. Beyond proficiency and regarding metacognition, foreign language proficiency may be "the cornerstone of the learner's strategic behavior and [it] magnifies the benefits of metacognitive knowledge on L2 reading" (Guo, 2018, p. 222). That is, highly proficient foreign language readers may employ metacognitive knowledge effectively and they can allocate and direct more cognitive resources instead of tackling with the constraining factors such as language structures or vocabulary items (Guo, 2018). Therefore, when learners' proficiency improves, metacognition might gain a predictive strength as van Gelderen, Schoonen, Stoel, de Glopper, and Hulstijn (2007) indicated.

In relation to assessment practices, we found that L2 readers do and/or may not necessarily employ metacognition although they might have some. In alignment with Reffyal, Pammu, and Sukmawaty's (2018) arguments, we also found that L2 readers did not always employ metacognitive regulation and 
this might relate to the nature of reading experiences. While presenting metacognition theory in 1979, Flavell stated that metacognitive experiences occur where highly conscious thinking is stimulated.Metacognitive experiences help individuals add, delete, and modify metacognitive knowledge and activate regulatory strategies for cognitive acts (Flavell, 1979). Therefore, when individuals are exposed to test experiences where higher order thinking kept limited or not required as in this study, they are unsurprisingly prone not to use metacognitive regulation.

Moreover, especially when metacognition is not practiced and assessed traditionally in classrooms (Ozturk, 2017a), learners' need for scaffolded-practice and their transfer of metacognitive knowledge for regulatory control over reading cannot be easily estimated. That is, learners might not readily develop responsibilities for metacognition. R2 in this study was the test with the best metacognitive reading experience and it showed through the correlation analysis. However, it also set a period until when participants persistently practiced metacognition in pairs or in the company of the researchers. After R2 test, participants started to practice metacognition on their own and they were not given assistance or guidance by the researchers or peers, unless asked. Absence of a correlation between R3 reading scores and metacognition regulation might; therefore, indicate participants' not practicing or taking responsibility for metacognitive regulation in the absence of a support. To this end, it might be that the acquisition process of metacognitive regulation requires prolonged scaffolding (Holton \& Clarke, 2006) or exposure to metacognitive experiences consistently to mechanize it.

Finally, this study also observed some findings that can contribute to our theoretical understanding of metacognition in L2 context. In this study, similar to Vandergrift and Tafaghodtari (2010) study, we found that low-and high-proficiency learners benefit from metacognitive training differently. Lowproficiency learners had more gains in metacognitive regulation while high-proficiency groups might have more refinement in metacognitive knowledge following metacognitive training. Specifically, for low- and mid-proficiency groups, metacognitive knowledge may undergo a decrease as learners gain metacognitive regulation over time. With high-proficiency group the trend, albeit, was in the reverse. Such trends may signal the interdependency of these two components (proficiency and metacognition) by which learners can rearrange metacognitive repertoires and may compare themselves to the ideals differently.

\section{Instructional Implications}

This study strongly emphasizes two aspects of education in relation to metacognition; instruction and assessment. We argue that reading performance and proficiency may be mediated by metacognition. For this purpose, a typical reading curriculum should include and explicitly present metacognition; teachers should know which metacognitive components are to be practiced weekly or every semester. Considering the effects of schooling in relation to learners' familiarity with L2 learning, individuals might already have sufficient metacognitive knowledge at college level; however, metacognitive regulation cannot be taken for granted. For these reasons, it is important for teachers to scaffold learners' metacognitive regulation for prolonged periods by involving them in various metacognitive experiences. Moreover, regarding metacognition-differences across different proficiency levels, trainings can be tailored to L2 proficiency levels rather than delivering a generic program in mixed proficiency classes. Therefore, learning outcomes can be maximized. However, this suggestion might not be always practical or compatible with institutional language education policies.

Moreover, as Ozturk (2017a) previously emphasized that metacognition is not traditionally assessed at schools. As a potential result of such a practice, its instruction may be easily ignored in classrooms or else, students might not simply see the relevance of or internalize metacognition for their future 
academic practices. For curriculum developers and policy makers, it is important to integrate metacognition into assessment practices by creating experiences where higher order thinking can be employed. As students practice metacognition not only during their classroom learning but also for assessment; metacognition can, therefore, become meaningful and essential.

\section{References}

Alsheikh, N. O., \& Mokhtari, K. (2011). An Examination of the Metacognitive Reading Strategies Used by Native Speakers of Arabic When Reading in English and Arabic. English Language Teaching, 4(2). https://doi.org/10.5539/elt.v4n2p151

Bandura, A. (1986). Social foundations of thought and action: A social cognitive theory. Englewood Cliffs, NJ: Prentice-Hall.

Bandura, Albert. (1971). Social learning theory. Morristown, NJ: General Learning.

Barnett, M. (1988). Reading through Context: How Real and Perceived Strategy Use Affects L2 Comprehension. The Modern Language Journal, 72(2), 150-162. https://doi.org/10.1111/j.15404781.1988.tb04177.x

Boulware-Gooden, R., Carreker, S., Thornhill, A., \& Joshi, R. M. (2007). Instruction of metacognitive strategies enhances reading comprehension and vocabulary achievement of third-grade students. The Reading Teacher, 61(1), 70-77.

Chern, C. L. (1993). Chinese students' word-solving strategies in reading in English. In T. Huckin, M. Haynes, \& C. Coady (Eds.), Second language reading and vocabulary learning (pp. 67-85). Norwood, NJ: Ablex.

Curwen, M. S., Miller, R. G., White-Smith, K. A., \& Calfee, R. C. (2010). Increasing teachers' metacognition develops students' higher learning during content area literacy instruction: Findings from the read-write cycle project. Issues in Teacher Education, 19(2), 127-151.

Flavell, J. H. (1979). Metacognition and cognitive monitoring: A new area of cognitive-developmental inquiry. American Psychologist, 34(10), 906-911.

Guo, L. (2018). Modeling the relationship of metacognitive knowledge, L1 reading ability, L2 language proficiency and L2 reading. Reading in a Foreign Language, 30(2), 209-231.

Holton, D., \& Clarke, D. (2006). Scaffolding and metacognition. International Journal of Mathematical Education in Science and Technology, 37(2), 127-143.

Iwai, Y. (2011). The Effects of Metacognitive Reading Strategies: Pedagogical Implications for EFL/ESL Teachers. The Reading Matrix, 11(2), 150-159. Retrieved from http://readingmatrix.com/articles/april_2011/iwai.pdf

Karami, S., \& Hashemian, M. (2012). The Relationship between (Meta)cognitive Strategies and Reading Comprehension in Iranian Female L2 Learners. International Journal of English Linguistics, 2(4), 58-64. https://doi.org/10.5539/ijel.v2n4p58

Mokhtari, K., \& Reichard, C. (2004). Investigating the strategic reading processes of first and second language readers in two different cultural contexts. System, 32, 379-394. https://doi.org/10.1016/j.system.2004.04.005

Muñiz-Swicegood, M. (1994). The effects of metacognitive reading strategy training on the reading performance and student reading analysis strategies of third grade bilingual students. Bilingual Research Journal, 18, 83-97. https://doi.org/10.1080/15235882.1994.10162659

Ozturk, N. (2015). A short review of research on metacognition training. Journal of Educational and Instructional Studies in the World, 5 (3), 50-62.

Ozturk, N. (2017a). Assessing metacognition: Theory and practices. International Journal of Assessment Tools in Education, 4(2), 134-148. 
Ozturk, N. (2017b). Identifying the Nature of Metacognition (Unpublished doctoral dissertation). University of Maryland, College Park, Maryland.

Phakiti, A. (2003). A closer look at the relationship of cognitive and metacognitive strategy use to EFL reading achievement test performance. Language Testing, 20(1), 26-56. https://doi.org/10.1191/02655322031t243oa

Pintrich, P. R. (2002). The role of metacognitive knowledge in learning, teaching, and assessing. Theory Into Practice, 41(4), 219-225.

Reffyal, M., Pammu, A., \& Sukmawaty. (2018). The Profiles of Metacognitive Reading Strategies of Successful and Unsuccessful EFL Learners of Senior High School. Jurnal Ilmu Budaya, 6(1), 136142.

Reza Ahmadi, M., Nizam Ismail, H., \& Kamarul Kabilan Abdullah, M. (2013). The importance of metacognitive reading strategy awareness in reading comprehension. English Language Teaching, 6(10). https://doi.org/10.5539/elt.v6n10p235

Salataci, R., \& Akyel, A. (2002). Possible Effects Of Strategy Instruction on L1 and L2 Reading. Reading in a Foreign Language, 14(1), 1-17.

Schraw, G. (1998). Promoting general metacognitive awareness. Instructional Science, 26(1), 113-125.

Schraw, G., \& Dennison, R. S. (1994). Assessing metacognitive awareness. Contemporary Educational Psychology, 19(4), 460-475. https://doi.org/10.1006/ceps.1994.1033

Takallou, F. (2011). The effect of metacognitive strategy instruction on EFL learners' reading comprehension performance and metacognitive awareness. Asian EFL Journal, 13(1), 272-300.

Tanner, K. D. (2012). Promoting student metacognition. Cell Biology Education, 11(2), 113-120.

Tavakoli, H. (2014). The effectiveness of metacognitive strategy awareness in reading comprehension: The case of Iranian university EFL students. Reading Matrix: An International Online Journal, 14(2), 314-336. Retrieved from http://www.readingmatrix.com/files/11-24o5q41u.pdf

Taylor, A., Stevens, J., \& Asher, J. W. (2006). The effects of explicit reading strategy training on L2 reading comprehension. In M. Norris, John \& L. Ortega (Eds.), Synthesizing research on language learning and teaching (pp. 213-244). Philadelphia: John Benjamins.

van Gelderen, A., Schoonen, R., Stoel, R. D., de Glopper, K., \& Hulstijn, J. (2007). Development of adolescent reading comprehension in language 1 and language 2: A longitudinal analysis of constituent components. Journal of Educational Psychology, 99(3), 477-491. https://doi.org/10.1037/0022-0663.99.3.477

Vandergrift, L., \& Tafaghodtari, M. H. (2010). Teaching L2 learners how to listen does make a difference: An empirical study. Language Learning, 60(2), 470-497.

Veenman, M. V. J., Van Hout-Wolters, B. H. A. M., \& Afflerbach, P. (2006). Metacognition and learning: Conceptual and methodological considerations. Metacognition and Learning, 1(1), 3-14. https://doi.org/10.1007/s11409-006-6893-0

Vygotsky, L. S. (1978). Mind in society: The development of higher psychological processes. Cambridge, MA: Harvard University Press.

Zhang, L. J. (2001). Awareness in reading: EFL students' metacognitive knowledge of reading strategies in an acquisition-poor environment. Language Awareness, 10(4), 268-288. https://doi.org/10.1080/09658410108667039

Zhang, L., \& Seepho, S. (2013). Metacognitive Strategy Use and Academic Reading Achievement: Insights from a Chinese Context. Electronic Journal of Foreign Language Teaching, 10(1), 5469.

Zimmerman, B. J. (2000). Attaining self-regulation: A social cognitive perspective. In M. Boekaerts, P. R. Pintrich, \& M. Zeidner (Eds.), Handbook of self-regulation (pp. 13-39). San Diego, CA: Academic.

Zimmerman, B. J. (2002). Becoming a self-regulated learner: An Overview. Theory Into Practice, 41(2), 
64-70. https://doi.org/10.1207/s15430421 tip4102

Zohar, A., \& Ben David, A. (2009). Paving a clear path in a thick forest: A conceptual analysis of a metacognitive component. Metacognition and Learning, 4(3), 177-195.

\title{
Yabancı dil olarak İngilizce okuma ikilemi: Üstbilişe karşı yeterlilik
}

\begin{abstract}
$\ddot{O} \mathbf{z}$
Bu çalışmanın amacı a) üstbiliş ve yeterliliğin yabancı dil olarak İngilizce okuma performansı üzerindeki etkilerini ve b) üstbiliş ve okuma performansı arasındaki ilişki incelemektir. Veriler Üstbiliş Farkındalık Envanteri (MAI) ile toplanmış ve okuma puanları incelenmiştir. Varyans analizleriyle, okuma puanlarının ve üstbiliş bilgisinin yeterlilik seviyelerinde farklılıklar gösterdiği ve zaman, zamanXsınıf ve zamanXyeterliliğinin üstbilişe etkisinin olmadığı bulunmuştur. Bunun yanı sıra, okuma sınavları üst düzey düşünme becerilerini içerdiğinde, katılımcıların üstbiliş bilgisi veya düzenlemeleri okuma puanlarıyla pozitif yönde ilişkili olduğu diger bir bulgudur. Üstbiliş farklılıkları açıklayabilen eğilimler bir örüntü izlemese de; farklı yeterlilik gruplarının eğitimlerden farklı şekilde yararlandığı ortaya çıkmıştır. Bu bağlamda üstbiliş eğitimi, düşük ve orta yeterlilik gruplarında üstbiliş düzenlemesinde hafif bir artı̧s ve yüksek yeterlilik grubu için, üstbiliş bilgisinde bir düzenlemeyi mümkün kılmıştır. Bu çalışmanın bulgular ışığında, öğretim ve ölçme-değerlendirmede, öğrencilerin yeterlilik düzeyleriyle uyumlu üstbiliş uygulamalarını öneriyoruz. Böylece, tüm öğrenciler üstbilişin gerekliliğini görebilir ve uygulama sorumluluğunu alabilirler.
\end{abstract}

Anahtar sözcükler: üstbiliş, yabancı dil olarak İngilizce, okuma, düzenleme, yeterlilik

\section{AUTHOR BIODATA}

Nesrin Ozturk studied her BA and MS at Middle East Technical University. A Fulbright scholar, Nesrin received her doctoral degree in Reading Education from the Department of Teaching and Learning, Policy and Leadership, College of Education, University of Maryland, College Park. Her research interests focus on K-12 and college level literacy practices, metacognition, reading assessment, and teacher education. She serves on the editorial boards of various journals i.e. The Reading Teacher, conferences i.e. AERA and LRA, and scientific committees. She provides workshops and in-service modules for professional development. Dr. Ozturk's passion for contributing to a democratic and 'just society' drives her to empower the youth and to celebrate freedom of mind. For her, a self-questioning and reflective intellect is the gateway to fulfill human potentials and to realize peace within individuals and around the world. She currently works at Ege University, School of Foreign Languages, Turkey.

Ferah Şenaydın works as a teaching fellow at Ege University and studies at ELT doctoral program at Bahçeşehir University with specific focus on applied linguistics and teacher education. In addition to teaching English, she has been engaged in international EU projects and in delivering workshops and trainings on international educational issues as part of these projects. 